University of Rhode Island

DigitalCommons@URI

2018

\title{
Oceans of Plastic: A Research Agenda to Propel Policy Development
}

Elizabeth Mendenhall

University of Rhode Island, mendenhall@uri.edu

Follow this and additional works at: https://digitalcommons.uri.edu/maf_facpubs

The University of Rhode Island Faculty have made this article openly available.

Please let us know how Open Access to this research benefits you.

This is a pre-publication author manuscript of the final, published article.

Terms of Use

This article is made available under the terms and conditions applicable towards Open Access

Policy Articles, as set forth in our Terms of Use.

Citation/Publisher Attribution

Mendenhall, E. (2018). Oceans of plastic: A research agenda to propel policy development. Marine Policy, 96, 291-298. doi: 10.1016/j.marpol.2018.05.005

Available at: http://dx.doi.org/10.1016/j.marpol.2018.05.005

This Article is brought to you for free and open access by the Marine Affairs at DigitalCommons@URI. It has been accepted for inclusion in Marine Affairs Faculty Publications by an authorized administrator of DigitalCommons@URI.For more information, please contact digitalcommons-group@uri.edu. 


\title{
Oceans of Plastic: A Research Agenda to Propel Policy Development
}

Elizabeth Mendenhall

mendenhall@uri.edu

215 Coastal Institute

1 Greenhouse Road

Department of Marine Affairs

University of Rhode Island

Kingston, RI 02881

\begin{abstract}
Although the phenomenon of marine plastic debris is now widely recognized as a problem for the international community, significant gaps in understanding still inhibit the creation and implementation of effective policy responses. This paper reviews the state of scientific knowledge about the causes and consequences of marine plastic debris, including its sources, pathways, composition, location, and impacts on ecosystems and human activities. Much remains unknown about the large scale impacts of plastic debris on ecosystem functions and human health, among other information gaps. Additional scientific research about the nature, extent, and harms of marine plastic debris could increase the political salience of the problem, and produce urgent and focused attention on the formulation of solutions. Although many policy responses have been proposed, and even pursued, additional research could assist in the prioritization of the most cost-effective strategies. The research agenda outlined would support a more detailed and comprehensive assessment of the nature of the problem of marine plastic debris, and inform the creation and implementation of effective solutions.
\end{abstract}

Keywords: marine plastic debris; marine pollution; scientific uncertainty; research agenda

Declaration of interest: none.

This research did not receive any specific grant from funding agencies in the public, commercial, or not-for-profit sectors. 


\section{Introduction}

Large amounts of plastic debris have been entering the ocean for many decades, yet only recently has this phenomenon been recognized as a major problem by the international community. Part of the explanation for this delayed realization relates to the distance, and relative invisibility, of marine plastic sinks in the center of ocean basins or on the sea floor. In the 1970s and 1980s, it was assumed that any land-based pollution would be obvious to the coastal state, which would bear the brunt of negative impacts and therefore have a strong incentive to mitigate pollution inputs, without need for international coordination [1]. The discovery of large concentrations of plastic in the North Pacific in the late 1990s was therefore a jarring experience. Through the efforts of individual advocates, the activities of nongovernmental organizations, and increased media attention, a much larger audience now harbors concerns about the amount of plastic in the ocean [2].

Despite a significant increase in scientific research on marine plastic debris since the turn of the century, we still lack important information about the sources, pathways, composition, and impacts of marine plastic debris [3]. Uncertainty about causes and consequences decreases the likelihood that effective solutions will be formulated and implemented. More research can clarify the impacts of marine plastic debris, which ensures that the issue remains politically salient [4]. Consolidation of evidence about harms also supports the strengthening and diffusion of environmental norms against plastic litter [5]. Scientific evidence makes possible a full costbenefit assessment that compares inaction to various regulatory options, which is critical to justify the sacrifices necessary to solve the problem [6]. And knowledge about the precise causes of harm, including the sources and pathways of plastics in the marine environment, informs the creation of targeted and maximally effective interventions.

This article surveys what is known about marine plastic debris, in order to identify areas of uncertainty that inhibit the formation of a clear, coherent, and consensus-based understanding of the problem. The first section considers the sources, pathways, locations, and composition of plastic debris sinks in the ocean. The second section addresses the reasons marine plastic debris is understood to be a pollution problem, and identifies the research still needed to establish the full scope of negative consequences for marine ecosystems and human uses of the ocean. The third section focuses on research which would be useful in the creation and implementation of particular solution sets. The overall goal is to outline an agenda for future research on marine plastic debris.

\section{Marine Plastic Sinks}

Marine plastic debris is a quintessential externality in that it is largely hidden from sight, harmful in a diffuse and difficult-to-quantify way, and exists primarily beyond the jurisdiction of any single nation-state. Understanding the problem requires information about where plastic debris comes from, where it ends up, and how it gets there. This section summarizes what is known about the sources, movements, locations, quantities, and composition of marine plastic debris in aggregate terms, and identifies areas of uncertainty that require additional research.

\subsection{Sources and Pathways}

Marine plastic debris is an externality of the on-going "plastic binge" that has become a pervasive feature of modern industrial civilization. Plastic is widely used in a variety of products, and at least half of all plastics are disposed after single use [7,8]. An inherent characteristic of 
plastic - its durability - explains both its appeal as a product and the challenge it presents for waste management. Because plastics take a very long time to naturally degrade, almost all the plastic ever created still exists. Of the plastic produced over the last century, only $9 \%$ has been recycled, with $12 \%$ incinerated and $79 \%$ deposited in landfills or the natural environment [9]. There are no rigorous estimates of the origins and totals for marine plastic debris as a proportion of all plastic waste [3]. But it is estimated that $10 \%$ of the plastic produced every year ends up in the oceans [10].

Researchers initially assumed that the majority of plastic waste found in the open ocean, and on the beaches of remote and uninhabited islands, came from ship dumping on the high seas [11]. By the late 1990s it became clear that poor management of waste on land was a significant source of marine plastic debris, which was dispersed across extremely long distances by winds and ocean currents [11].

Plastic debris enters the ocean through a variety of pathways, including coastal recreation, wastewater outflows, wind and rivers, accidental spills, leaching from landfills, discarded or lost fishing gear, and storm surges during extreme weather events. Pathways vary depending on an item's size and composition. The smallest pieces - nano and micro plastics often come from cosmetics, cleaning, medicine, and personal hygiene products, and enter the marine environment through waste water outflows [7]. The water used to launder clothing made from synthetic fabrics is a significant source of microplastic fibers; a single garment may lose around 2000 plastic fibers per wash [12]. Nano-plastics used for agricultural or industrial uses, such as small-scale manufacturing using 3D printers, are often windblown into the marine environment [13]. Although land-based outflows contribute the majority of marine plastic debris, ocean-based sources are still significant. It is estimated that half of ocean-based plastic debris comes from commercial fishing boats, although the primary source of data on discarded or lost fishing gear comes from the fishers themselves [7,14].

It is widely cited that eighty percent of marine plastic debris comes from land, and twenty percent from ships. This estimate is not supported by robust data, however. There are "no direct estimates of plastic input to the ocean," and no reliable global estimates of ship based pollution, discarded fishing gear, or the debris that enters the marine environment as a result of natural disasters [14]. Rivers are likely a large source of land-based plastic pollution, but there is no data to support estimates of how much debris becomes immobilized in the sediment or on the banks of rivers, and how much gets carried out to sea [15].

In terms of land-based sources of debris, policymakers are often interested in how much comes from which countries. The quantity of plastic debris that enters the ocean depends largely on population size and the quality of waste management [3]. Although many countries contribute to marine plastic debris, many of the worst offenders are Asian coastal developing states $[7,16]$. Several African states are also top contributors. The United States is responsible for a significant proportion of marine plastic debris, largely because of high per capita consumption and disposal of plastic products [17]. The most commonly cited list of top contributor states comes from a single study, which combines available data on total waste with a model that predicts waste mismanagement. The study focuses on waste from within 50 kilometers of the coast, and may therefore underestimate the load carried by rivers from inland sources. The authors acknowledge that the estimates suffer from uncertainty related to limited data on waste generation, composition, collection, and disposal outside urban areas, and do not account for illegal dumping or the import and export of waste internationally [3]. Lack of data, and variation in 
methodologies for sampling, makes it very difficult to produce an accurate estimate of total quantities, and top contributors, of marine plastic debris [18].

Plastic debris has been found in every major ocean, but how plastic arrives at various ocean sites remains unclear; there is "deep ignorance and high uncertainty" about the exact pathways for plastic in the marine environment [19]. There is limited knowledge of how floating debris moves, and at what speeds, as a result of wind and currents. Experimental studies are needed to determine the precise trajectories and routes of marine debris [20].

\subsection{Composition and Distribution}

Plastic fragments are generally identified by size - macro-plastics, micro-plastics, and nano-plastics - but authors disagree about the distinctions between these categories. Microplastics are alternatively described as less than $5 \mathrm{~mm}$ or less than $1 \mathrm{~mm}$, and nanoplastics as less than $200 \mathrm{~nm}$ or less than $100 \mathrm{~nm}$. Some researchers use additional categories such as 'mesoplastics' and 'megaplastics,' which creates inconsistency in the use of the term 'macroplastics' (usually greater than $5 \mathrm{~mm}$ or greater than $25 \mathrm{~mm}$ ). Some items enter the ocean very small, such as plastic microbeads or synthetic fibers. But larger plastics also degrade into micro- and nano-sized pieces, as a result of UV radiation, mechanical abrasion, 'biofouling' such as microbial colonization, and other processes [21]. Little is known about how quickly different types of plastics break down in different marine settings [14]. It is unclear whether primary or secondary microplastics predominate, although limited samples suggest that most marine microplastics are the result of degradation in the marine setting [22].

Scientific research about micro and nanoplastics is "still in its infancy" [2]. Because of the challenges of sampling, scientists do not have a clear idea of the amount, density, or distribution of microplastics in the ocean environment $[23,24]$. It is very difficult to reliably separate microplastics from organic debris in field settings. Nanoplastics are the "least known area of marine litter," in terms of sources, prevalence, and effects [25]. There are no estimates of the amount of nanoplastics in the ocean because "no methods exist for the reliable detection of nanoplastics in samples" [26]. But it is clear than micro and nanoplastics exist throughout the ocean.

Plastic debris is distributed across every major ocean, and throughout the water column [7]. One study found that, despite there being more sources of plastic in the northern hemisphere, plastic debris seems to exist in comparable amounts in both northern and southern parts of the ocean. This may be because of overlooked pathways, or because of differential rates of breakdown and sinking (where there is more plastic in the northern hemisphere, but more of it sinks and is therefore unaccounted for) [22]. In general, plastic debris does not diffuse evenly across the ocean [27]. Churning water facilitates vertical mixing, and the buoyancy of plastic can change as it degrades and attracts communities of microorganisms [23]. The density of debris in any given location depends on the nature of the plastic items, their initial entry point into the ocean, air and water currents, and other natural and anthropogenic factors [27]. For these reasons, the type and density of debris can differ between areas of accumulation.

It is widely understood that marine plastic debris accumulates in sub-tropical 'convergence zones' or gyres. These gyres exist in near the centers of ocean basins because of 'Ekman transport', a current effect created by the complex interaction of the Earth's rotation and wind patterns. Five such accumulation zones have been identified: two in the Atlantic, two in the Pacific, and one in the Indian Ocean. Models also predict the existence of plastic accumulation areas in semi-enclosed seas such as the Mediterranean, and high concentrations of debris have 
been found in the Bay of Bengal, South China Sea, and Gulf of Mexico [19,28]. A large concentration of plastic debris was recently identified in the Arctic [29]. The northern-moving branch of North Atlantic thermohaline circulation has been described as a "plastic conveyor belt" that transports debris into the Greenland, Norwegian, and Barents Seas. This part of the Arctic Ocean concentrates an estimated $95 \%$ of plastic in the Arctic region [28]. In the case of gyres, scientists estimate that it takes up to two years for a piece of debris to travel from a coastal zone to an oceanic gyre, but once it reaches the gyre it is unlikely to migrate elsewhere [27]. The result is persistent patches of floating debris, referred to as "garbage patches" by popular media.

Although the garbage patches are the most visible manifestation of marine plastic debris, they do not represent the full scale of the problem. Estimates of the total amount of plastic debris tend to focus on the sea surface. A 2014 synthesis of everything known about the abundance and distribution of marine plastic debris found that "the global load of plastic on the open ocean surface was...far less than expected" [30]. The remaining plastic is either suspended in the water column, deposited on beaches, or accumulated on the seafloor, but little is known about the types and amounts of plastics in these places [22]. In terms of beaches, more work is needed in the creation of representative sampling designs that can reliably establish the degree and distribution of plastic deposition [31]. Determining whether beaches are a sink or simply a waypoint for plastic requires deeper sampling, but most studies focus on the top few centimeters of beach sediment [32].

Observation of plastic debris on the seafloor is difficult and costly compared to beaches or the sea surface. But as scientific data collection advances, "benthic litter is progressively being revealed to be more widespread than previously assumed" [27]. Two recent estimates of the proportion of marine debris on the seafloor demonstrate a lack of certainty: one suggests that it may be $50 \%$, while the other suggests $70 \%[14,33]$. Several marine processes facilitate sedimentation, including coastal storms, currents associated with thermohaline circulation, and down welling enhanced by seafloor topography. Some plastic sinks when its buoyancy changes due to biofouling [34]. It is unclear whether sinking reduces the likelihood or rate of degradation. While the high pressure may facilitate the breakdown of plastics in the deep ocean, debris there is also shielded from UV radiation [7,35].

Little is known about overall trends in deep sea accumulation of plastics, as only specific areas have been sampled [18]. Most studies of benthic marine litter concentrate on continental shelves and popular fishing grounds [14]. Unrepresentative samples do suggest that plastic microfibers are "ubiquitous in the deep sea" [36]. It is entirely possible that significant deep sea accumulation zones will be discovered as a result of additional research. Estimating trends in deep sea accumulation will be extremely difficult because of the lack of baseline data, and limited understanding of how plastic ages and degrades at depth [18].

\section{Marine Plastic Pollution}

Many of the harms associated with marine plastic debris have been known about for decades, although not their full extent. The consumption of plastic by seabirds was reported as early as the 1960s, and plastic debris began to be coded as a pollution issue as early as the 1970s $[7,33]$. The main concern throughout the 1980s, however, was the "specter of fouled beaches" [37]. A wider range of consequences has only become clear in the last few decades, and especially the last ten years. A recent survey of available scientific research identified a "gap in information needed to evaluate impacts of marine debris on coastal and marine species, habitats, 
economic health, human health and safety, and social values" in addition to a "gap in capacity" in establishing the significance of the problem for global audiences [27]. Although there is a significant "gap in understanding" about the impacts of marine plastic debris on socio-economic systems, the most glaring lacunas concern the effect on ocean ecosystems, functions, and Earth systems [19]. This section surveys the state of scientific knowledge about the impacts of marine plastic debris.

\subsection{Impacts on Ecosystems}

The introduction of plastic into marine environments disrupts the normal behavior of plants and animals, and the normal functioning of ecosystems. Several distinct impacts can be identified.

Macro-plastics can entangle marine animals, and micro- and nano-plastics can be ingested by animals at various trophic levels. More is known about the effects of entanglement than ingestion [38]. Over 660 marine species have been shown to be adversely affected by encounters with plastic, including all species of sea turtles, two-thirds of all marine mammal species, and half of all seabird species $[11,39]$. The physiology and behavioral characteristics of certain species makes them more vulnerable to entanglement, such as the plunging method of feeding used by some seabirds. Entanglement or ingestion can reduce the quality of life, survival chances, and reproductive viability of marine animals, or kill them through strangulation, suffocation, or starvation [11].

Most studies on ingestion occur in laboratory settings, and those undertaken in field settings often have problems with bias as a result of evaluating the subset of the population found injured or dead [40,41]. Many studies simply report the numbers of dead animals found with debris in their digestive tracts, without demonstrating that death was caused by ingestion [42]. It is unclear how much ingestion of microplastics occurs, or how much is retained or egested by individual organisms. Without this data it is impossible to estimate the overall effect of microplastic ingestion on populations and food chains [43]. And studies of ingestion tend to focus on charismatic megafauna, so that little is known about the impacts on less visible and exciting marine invertebrate [44]. No studies examine the effect of encounters with debris on deep ocean species.

Ingestion may contaminate sea life with plastic additives, or toxins that concentrate on plastics as they float in seawater [45]. Much less is known about these effects compared to entanglement and ingestion [41]. Even when chemicals leached from plastics do not directly harm tissues, they can have endocrine disruptor effects [46]. Debris items often accumulate high concentrations of persistent organic pollutants from the water column [23,47,48]. Microplastics in particular, because of their high ratio of surface area to volume, tend to be a vector of concentrated toxins [27]. More studies are needed to assess which types, sizes, and ages of plastic attract or leach which pollutants, and at what rate. And we lack a full understanding of the "total pollutant loads" associated with chemical additives in plastics [8]. In terms of animals who eat plastics, little is known about the degree and rate of absorption, and the effects of long term exposure to these toxins [7].

Species-specific laboratory studies suggest that ingestion of plastics can have "sub-lethal or chronic effects" with long-term consequences for survival [7]. Copepods - an important part of marine food chains - have been found to ingest microplastic, with adverse consequences for fecundity and reproduction [19]. Research on mussels and crabs suggests that plastic pieces are subject to "trophic transfer," moving up the food chain through predator-prey relationships [49]. 
More research is needed to determine the full extent of trophic transfer. More advanced species also suffer from direct interactions with microplastics [12]. A study on the larval form of European perch found that microplastics caused physical and chemical changes that negatively impacted development. When exposed to microplastic polystyrene, perch larva hatched less, grew slower, ate differently, and avoided predators less successfully [50]. There is evidence that nano-plastics can penetrate biological membranes and disrupt the normal functioning of cells [13]. One study found that nanoplastic polystyrene can be taken up through the gills of adult fish, and eventually become trapped in internal organs, including the brain. The resulting impacts on the "organization and function of biological membranes" were provisionally linked with observed behavioral changes, such as impaired feeding activity [21].

Marine plastic debris can also harm marine life by smothering and abrading habitats such as coral reefs. These ecosystems contain many animals that eat by using tiny filaments to filter the seawater that flows around them, and which are therefore sensitive to sustained contact with plastics. Structurally complex corals are especially vulnerable. Repeated abrasions may over-tax immune responses, weakening the coral, and plastic can be a disease vector. One recent study of 124,000 corals on 159 different reefs found that the risk of disease increases from $4 \%$ to $89 \%$ when plastic debris is present [51]. Because coral reefs are critical and biodiverse habitats, the presence of plastic may harm overall fisheries productivity and biodiversity. The overall prevalence and quantitative impact of these effects is unknown.

Concern about marine plastic debris as a potential vehicle for invasive species increased after debris from the 2011 Japanese tsunami started washing up on the Pacific coasts of North America, carrying 289 identified invasive species, some of which had survived for almost 6 years. Although none of these trans-oceanic voyagers are known to have established invasive communities, the prevalence of marine plastic debris marks a qualitative shift in the routes for and risk of invasive marine species. Compared to organic debris, plastic can travel farther and longer before breaking down. And marine plastic debris moves slowly, allowing sessile organisms to populate, and often travels in large mats, allowing the transfer of larger communities. The result is a new vehicle for the trans-oceanic dispersal of marine species [52]. However, there is currently insufficient evidence to definitively state that marine plastic debris has rearranged local ecosystems in disruptive ways [27]. More research is needed to determine whether plastic debris increases the probability of invasive species taking hold, relative to existing mechanisms like natural debris, ship biofouling, and ballast water [42].

The impact of marine plastic debris on entire ecosystems cannot be ascertained with the quantity and quality of current evidence, because most studies have focused on single species, been conducted in laboratory settings, and/or focus on sub-organism or organism level impacts $[2,19]$. One major obstacle to 'scaling up' scientific findings is a lack of baseline data about populations or assemblages, which would support conclusions about the effect of marine plastic debris on those levels. Evidence that individuals die as a result of encounters with plastic is insufficient to prove a population effect, because characteristics of those individuals (such as age) may make them less important to overall population growth. Another difficulty is the lack of knowledge about mechanisms that connect sub-organism effects on tissues or organs to ecological impacts on populations or communities [42]. Although sometimes an 'indicator species' can be chosen as a proxy for overall environmental effects, there is not currently enough data to connect any specific species with a specific metric for environmental quality [14].

The ecological assessments that might be possible with more data could help identify potential impacts on the provision of ecosystem services [42]. It may even prove to be that 
marine plastic debris is so significant that it disrupts Earth systems and processes. An example of a potential disruption at the Earth system scale concerns the flow of nutrients and sequestration of carbon: if fecal matter is more buoyant because of the presence of low density plastics, the movement of both nutrients and carbon into the deep ocean could be significantly reduced [19]. Although there is reason to believe that ecosystem services of this type may be impacted, we do not have enough information to say with certainty.

\subsection{Impacts on Human Activities}

In addition to the negative consequences for marine ecosystems described above, plastic debris entails direct and indirect impacts on human activities. Plastic litter on popular beaches has been one of the most obvious and visible parts of the problem, with clear harm to aesthetic values and tourism economies [11]. Debris removal can be very expensive. On the west coast of the United States, cleaning beaches costs half a billion dollars each year [47]. Plastic litter is also a challenge for commercial ships and recreational boats, which are subject to 'propeller fouling' $[11,27]$. Encounters with plastic create additional burdens for fishing and aquaculture, requiring the removal of debris from nets, traps, pens, and racks. These negative impacts reveal a common theme: marine plastic debris creates new burdens, tasks, and costs for economic activities associated with the ocean. The literature on the total economic costs of these disruptions has been described as "very sketchy," and studies are hampered by a lack of data about cleanup expenditures [53].

Scientists are beginning to understand that plastic particles have also infiltrated and tainted the supply of seafood, but studies are limited to particular locations and species. A recent survey of fish caught in the English Channel found that over one-third had plastic in their digestive tracts. The survey included surface and bottom dwelling fish, and commercial species such as cod and haddock, and concluded that plastic ingestion was common in the English Channel [54]. Another study found that both farmed and wild bivalves, such as mussels and oysters, contained microplastics [23]. It is difficult to estimate the total exposure to plasticinfused seafood, in part because of the lack of studies on different commercial species. A recent study of seafood sold on markets in Indonesia and California found that one-quarter of fish and one-third of shellfish sampled contained anthropogenic debris, primarily plastics and synthetic fibers [55]. It has been estimated that the top European seafood consumers ingest up to 11,000 pieces of plastic every year [23].

The exact impact of ingesting microplastics from seafood is unclear, because little is known about the transfer of toxins to human consumers [6,41]. But there is reason to believe food safety may by negatively impacted, as plastics leach additives and accumulated persistent organic pollutants. The phenomenon of bioaccumulation suggests that chemicals from plastic debris, transferred to fish and then to humans, may present a real human health risk [55]. And the presence of micro-plastics in the digestive system may increase the risk of infection [23]. The impact of even smaller nano-plastics is also unknown, although there is evidence that these particles become embedded within tissues and are transferred up the food chain, potentially also to humans. Although it is clear that plastic in seafood will have implications for human consumers, the exact consequences are "not well recognized or understood" [10].

The presence of marine plastic debris may be depressing overall fisheries productivity, therefore reducing available fish biomass. Polystyrene nanoparticles reduce the fitness of individual fish by altering their metabolisms and behaviors, with disruptive consequences for entire ecosystems. These nano-particles infect the food chain from the lowest algae to the top 
consumer. Nano-plastics may disrupt photosynthesis in primary producers [13]. The presence of nano-plastics has been described as a "potent future environmental threat to the function of natural ecosystems" [21]. Any reduction in fish biomass would have negative implications for food security, with especially severe consequences for coastal areas with abundant debris and a high reliance on fish for protein [55].

\section{Marine Plastic Solutions}

Because the problem of marine plastic debris spans multiple policy areas - including coastal management, waste management, product design, chemical regulation, and consumer protection - there are many opportunities for the creation of regulatory solutions [14]. Policy responses typically fall within one of three categories: mitigation of the amount of plastic entering the ocean, reduction in the amount of harm caused by that plastic, and remediation or cleanup of plastic already in the ocean. The choice of an effective solution set among these options will require further research about the production, consumption, and disposal practices surrounding plastics, as well as the technological possibilities for reducing its use and harms, and for capturing it once it has entered the marine environment.

\subsection{Product Design}

The original source of all marine plastic debris is consumer products, parts, and packaging made out of plastic materials. Plastics are an "archetypically linear sector," with the end of the production-consumption-waste chain often being natural environments like the ocean [56]. In the 1980s there was significant optimism about recycling as a way to reintegrate waste streams into production, but recycled plastics have generally been economically uncompetitive with virgin material, so much of what is collected for recycling never actually gets recycled [57]. More recent proposals focus on the use of biopolymers, which promise a "truly biodegradable" alternative to plastic [27]. Biodegradable polymers are not a panacea, however. They would not be suitable for all products, and may not solve all the problems associated with microplastic debris $[8,58]$. And plant-based biopolymers would require increases in agricultural production, with negative environmental implications [4]. More research is needed to evaluate the potential of bioplastics produced through the metabolic pathways of microbes. While microbial bioplastics have potential as plastic replacements, their cost effectiveness and true biodegradability remain open questions [59].

Less revolutionary changes in product design may be more effective at mitigating the amount and limiting the effects of marine plastic debris. The most useful product design changes would reduce or eliminate the obsolescence of plastic products, by making them more durable, reusable, or recyclable [37]. Additional research about the sources and harms of marine plastic debris could focus attention on the re-design of products that are most likely to contribute to the problem [8]. More information is needed about which types of plastics and plastic products are most likely to end up in the ocean, break down into microplastics, concentrate toxins, harm marine animals, or be found in seafood. This research, paired with an assessment of which products could be re-designed without significantly altering their utility, could help generate list of product changes that are relatively easy to do, while being maximally impactful. Possible examples include adjusting the size of nanoplastics in order to reduce harm to tissues and organs of marine animals, or producing textiles that shed fewer fibers during washing $[11,60]$. 


\subsection{Product Bans}

One of the most significant and widespread interventions by governments thus far has been the prohibition and discouragement (via economic penalty) of two types of plastic product: microbeads and carrier bags. The number of policies targeting microbeads, also described as primary microplastics, has increased in the last few years, although their effectiveness is difficult to assess due to their recent and inconsistent implementation [61]. Plastic bag bans or taxes are more common, and seem to reduce the amount of plastic entering the waste stream [62]. Another common form of intervention provides positive incentives for returning and/or recycling disposable plastic containers, such as beverage bottles. The idea is that creating a refund value incentivizes "informal waste collection" [4]. Initial evidence suggests that, where implemented, these positive incentives reduce the amount of plastic litter [63]. Several of these initiatives have been covered at length elsewhere in this special issue of Marine Policy.

In general, however, it is difficult to assess the exact contribution of these policies to mitigating marine plastic debris. There is a need for "standardized monitoring protocols" that use rigorous sampling and statistics to assess change in debris inputs across scales [27]. In the case of plastic bags, initial findings that demonstrate fewer bags in the local environment could be supplemented with more rigorous research on environmental outcomes. Research on microbead densities at wastewater treatment plants before and after bans could help ascertain the effectiveness of these policies [61]. Studies of this type could also support the creation of costeffective monitoring protocols for governments with low capacity to verify and enforce bans.

If bans and levies do work, more fine-grained data about the composition of marine plastic debris could focus attention on other candidates for these policies, such as plastic straws and utensils. Although these products are anecdotally known to harm wildlife, these effects are not always well documented scientifically [41].

\subsection{Waste Management}

Improvements in waste management systems may be the single most effective means of mitigating marine plastic debris, but because waste disposal is typically managed at local levels, and since waste collection and treatment infrastructure varies widely, there is no 'one size fits all' solution. Many of the biggest contributors to marine plastic debris simply need to build more infrastructure for waste collection and treatment [4]. Improving waste management systems in developing countries will require significant resources, but is "paramount" to reducing inputs of plastic into the marine environment [3]. More detailed (and data intensive) research about the sources of plastic debris can increase the cost-effectiveness of decisions about resource allocation for improving waste management systems.

One commonly proposed solution is for governments to simply classify plastic trash as 'hazardous waste'. Doing so would make plastic waste disposal a matter of national, as opposed to local, responsibility [57]. In the United States, such a designation would immediately open up new funds and regulatory powers to control plastic inputs into the environment, clean up plastic litter where it accumulates, and shift the burden of proof (that plastics are safe) onto the plastics industry [64]. Because a blanket classification of plastic as hazardous waste would be economically disruptive and strongly opposed by many industries, a policy shift of this magnitude is highly unlikely. But incrementally classifying the most harmful plastics as hazardous, such as those that easily break down into microplastics, or those that contain the most harmful additives, is more politically possible and economically palatable. More research is needed about which plastic types and products might qualify as 'hazardous waste.' 
The recent discovery of bacterial enzymes that break down certain types of plastic has prompted significant optimism about the use of "plastic eating bugs" in waste management, with some scientists heralding a "paradigm shift" in what is considered biodegradable [65-67]. Although these enzymes have been shown to biodegrade some commonly used plastics, their demonstrated capability is neither thorough nor efficient enough to be usable on a large scale $[68,69]$. More research is needed to understand the precise mechanism by which this enzyme degrades plastics, and to determine which types of plastic can be degraded through this process [68]. Perhaps most significantly, additional research is needed to "find and engineer" enzymes that will break down plastic more efficiently [67].

\subsection{Capture and Cleanup}

Collection and capture of marine plastic debris has been described as a "Sisyphean task," given the continued flow of plastic inputs [4]. And it would be a very large task, given the vastness of the ocean and the scale of the problem [70]. Collection of microplastics may be impossible due to their small size, and incorporation into the marine ecosystem [3,7]. But the sense that remediation is an impossible task may be a result of information deficiency more than an actual lack of utility.

There are some examples of success in debris collection in harbors and coastal waters [7]. South Korea in particular has invested in equipment for debris removal on the seabed, and debris collection in areas of high accumulation [33]. Research is needed to establish how effective these technologies might be in different locations, such as the mouths of rivers, the open ocean, and at different depths. Theoretically, a limited number of debris collectors placed at strategic locations, to take advantage of currents and debris flows, could capture a large amount of marine debris. Locations could also be chosen to reduce the impact on species during especially vulnerable parts of their lifecycle. Although remediation is unlikely to be a complete solution, it may be able to reduce that amount of debris that breaks down into microplastics, or sinks to the deep seabed. Because there is so much plastic in the ocean already, the negative consequences of marine plastic debris may be unavoidable without investment in some type and level of remediation.

\section{Conclusion}

Scientists and environmentalists often argue that we know enough about marine plastic debris to take action to address it $[2,42,64]$. While it may be true that we know enough to know that we need to do something, existing evidence of the harms of plastic debris, and research on how to ameliorate them, seems to be insufficient for generating the urgency and focused attention required to formulate and implement effective solutions. The "major gaps in scientific knowledge" outlined here hinder response strategies for two reasons: they do not paint a full picture of why plastic debris should be addressed, and they provide incomplete information about how plastic debris is best addressed [8]. The 'weight of evidence' is still too light regarding the extent and distribution of sources, pathways, and sinks, and the large scale impacts to economies, ecosystems, and human health (see Table 1). A deeper base of scientific evidence can also help to identify the thresholds for Earth system disruptions and the consequences for provision of ecosystem services, and serve as the evidence-based policy platform for the generation of binding international conventions with broad legitimacy. 
Table 1 - Scientific research questions regarding marine plastic debris

\begin{tabular}{|c|c|}
\hline $\begin{array}{c}\text { Characteristics } \\
\text { of Marine } \\
\text { Plastic Debris }\end{array}$ & Scientific research questions that currently have insufficient answers \\
\hline Sources & $\begin{array}{l}\text { How much plastic ends up in the ocean? } \\
\text { What proportion actually comes from land-based sources? } \\
\text { How much plastic enters the ocean from rivers? } \\
\text { How much plastic enters the ocean as a result of natural disasters? } \\
\text { How much fishing gear is lost or discarded into the ocean? } \\
\text { How accurate are current estimates of top country contributors? }\end{array}$ \\
\hline Pathways & $\begin{array}{l}\text { How does plastic debris move in the marine environment? } \\
\text { What factors determine the movement of plastic debris? }\end{array}$ \\
\hline Composition & $\begin{array}{l}\text { How should debris size be categorized? } \\
\text { Microplastics: total amount, density, and distribution } \\
\text { Nanoplastics: sources, amounts, effects } \\
\text { How quickly do different types of plastic break down in different marine environments? } \\
\text { Are most micro/nano-plastics in the ocean primary or secondary? }\end{array}$ \\
\hline Distribution & $\begin{array}{l}\text { How much plastic, and of what type, resides in the water column, on beaches, and on the } \\
\text { seafloor? } \\
\text { How does the deep ocean environment alter the rate of breakdown? } \\
\text { Are there accumulation zones for plastic debris on the seafloor, and if so, where are they? }\end{array}$ \\
\hline $\begin{array}{l}\text { Impacts on } \\
\text { Ecosystems }\end{array}$ & $\begin{array}{l}\text { Ingestion: which species and individuals? How often? Which plastics? } \\
\text { How much plastic is egested, and how often? } \\
\text { By what mechanism(s) does ingestion harm animals? } \\
\text { Do chemicals transfer from ingested plastic to animals? } \\
\text { Which plastics attract or leach pollutants, and at what rate? } \\
\text { How does long term exposure to these toxins affect sea life? } \\
\text { How much, and by what pathways, does plastic transfer between trophic levels? } \\
\text { How does ingestion of nano/microplastics affect physiology and behavior of different species? } \\
\text { How prevalent and impactful is the harm to coral reefs? } \\
\text { Has marine plastic debris increased the risk of invasive species? } \\
\text { How are impacts on the organism level connected to population or ecosystem scale effects? }\end{array}$ \\
\hline $\begin{array}{l}\text { Impacts on } \\
\text { Human } \\
\text { Activities }\end{array}$ & $\begin{array}{l}\text { How much money is spent on beach cleanup worldwide? } \\
\text { How much do encounters with marine plastic debris cost ocean-based industries? } \\
\text { What commercial species are contaminated with plastics? } \\
\text { How does eating plastic-contaminated seafood affect human consumers? } \\
\text { Does the presence of marine plastic debris affect overall fisheries productivity? }\end{array}$ \\
\hline Product Design & $\begin{array}{l}\text { Can microbes be used to produce viable biopolymers? } \\
\text { Which products are the most likely to become marine debris? } \\
\text { Which products are the most harmful as marine debris? } \\
\text { Which products could be re-designed without significant loss of utility? }\end{array}$ \\
\hline Product Bans & $\begin{array}{l}\text { How can the evaluation of product bans, penalties, and positive incentives be standardized? } \\
\text { How effective are product bans and levies? }\end{array}$ \\
\hline $\begin{array}{c}\text { Waste } \\
\text { Management }\end{array}$ & $\begin{array}{l}\text { Which local waste management systems should be prioritized for infrastructure improvement? } \\
\text { Which types of plastic products could be feasibly categorized as 'hazardous waste'? } \\
\text { How efficiently can plastic-degrading enzymes break down plastics? Which types can be } \\
\text { broken down? How does the degradation work? }\end{array}$ \\
\hline $\begin{array}{l}\text { Capture and } \\
\text { Cleanup }\end{array}$ & $\begin{array}{l}\text { Where should plastic collectors be placed for maximal efficiency and minimal harm to the } \\
\text { marine environment? }\end{array}$ \\
\hline
\end{tabular}




\section{Acknowledgements}

An early version of this paper was presented at the International Studies Association conference.

The author would like to thank Alastair Iles, Peter Stoett, Joanna Vince, and the editorial team at Marine Policy. 


\section{References}

[1] E.A. Kirk, Science and the International Regulation of Marine Pollution, in: D.R. Rothwell, A.G. Oude Elferink, K.N. Scott, T. Stephens (Eds.), Oxf. Handb. Law Sea, Oxford University Press, 2017: pp. 516-535.

[2] C.M. Rochman, A.-M. Cook, A.A. Koelmans, Plastic debris and policy: Using current scientific understanding to invoke positive change: Plastic debris and policy, Environ. Toxicol. Chem. 35 (2016) 1617-1626. doi:10.1002/etc.3408.

[3] J.R. Jambeck, R. Geyer, C. Wilcox, T.R. Siegler, M. Perryman, A. Andrady, R. Narayan, K.L. Law, Plastic waste inputs from land into the ocean, Science. 347 (2015) 768-771. doi:10.1126/science.1260352.

[4] N. Simon, M.L. Schulte, Stopping Global Plastic Pollution: The Case for an International Convention, Heinrich Böll Foundation, 2017.

[5] P. Dauvergne, The power of environmental norms: marine plastic pollution and the politics of microbeads, Environ. Polit. (2018) 1-19. doi:10.1080/09644016.2018.1449090.

[6] K. Raubenheimer, A. McIlgorm, Is the Montreal Protocol a model that can help solve the global marine plastic debris problem?, Mar. Policy. 81 (2017) 322-329. doi:10.1016/j.marpol.2017.04.014.

[7] W.C. Li, H.F. Tse, L. Fok, Plastic waste in the marine environment: A review of sources, occurrence and effects, Sci. Total Environ. 566-567 (2016) 333-349. doi:10.1016/j.scitotenv.2016.05.084.

[8] S. Pettipas, M. Bernier, T.R. Walker, A Canadian policy framework to mitigate plastic marine pollution, Mar. Policy. 68 (2016) 117-122. doi:10.1016/j.marpol.2016.02.025.

[9] R. Geyer, J.R. Jambeck, K.L. Law, Production, use, and fate of all plastics ever made, Sci. Adv. 3 (2017) e1700782. doi:10.1126/sciadv.1700782.

[10] K. Mattsson, E.V. Johnson, A. Malmendal, S. Linse, L.-A. Hansson, T. Cedervall, Brain damage and behavioural disorders in fish induced by plastic nanoparticles delivered through the food chain, Sci. Rep. 7 (2017). doi:10.1038/s41598-017-10813-0.

[11] M.R. Gregory, Plastics and South Pacific Island shores: environmental implications, Ocean Coast. Manag. 42 (1999) 603-615. doi:10.1016/S0964-5691(99)00036-8.

[12] M.A. Browne, P. Crump, S.J. Niven, E. Teuten, A. Tonkin, T. Galloway, R. Thompson, Accumulation of Microplastic on Shorelines Woldwide: Sources and Sinks, Environ. Sci. Technol. 45 (2011) 9175-9179. doi:10.1021/es201811s.

[13] J.P. da Costa, P.S.M. Santos, A.C. Duarte, T. Rocha-Santos, (Nano)plastics in the environment - Sources, fates and effects, Sci. Total Environ. 566-567 (2016) 15-26. doi:10.1016/j.scitotenv.2016.05.041.

[14] M. Niaounakis, The Problem of Marine Plastic Debris, in: Manag. Mar. Plast. Debris, Elsevier, 2017: pp. 1-55. doi:10.1016/B978-0-323-44354-8.00001-X.

[15] C. Schmidt, T. Krauth, S. Wagner, Export of Plastic Debris by Rivers into the Sea, Environ. Sci. Technol. 51 (2017) 12246-12253. doi:10.1021/acs.est.7b02368.

[16] R. Harrabin, UN signals "end" of throwaway plastic, BBC News. (2017). http://www.bbc.com/news/science-environment-42252233.

[17] Seven charts that explain the plastic pollution problem, BBC News. (2017). http://www.bbc.com/news/science-environment-42264788.

[18] F. Galgani, G. Hanke, T. Maes, Global Distribution, Composition and Abundance of Marine Litter, in: M. Bergmann, L. Gutow, M. Klages (Eds.), Mar. Anthropog. Litter, 
Springer International Publishing, Cham, 2015: pp. 29-56. doi:10.1007/978-3-319-165103.

[19] P. Villarrubia-Gómez, S.E. Cornell, J. Fabres, Marine plastic pollution as a planetary boundary threat - The drifting piece in the sustainability puzzle, Mar. Policy. (2017). doi:10.1016/j.marpol.2017.11.035.

[20] T. Kiessling, L. Gutow, M. Thiel, Marine Litter as Habitat and Dispersal Vector, in: M. Bergmann, L. Gutow, M. Klages (Eds.), Mar. Anthropog. Litter, Springer International Publishing, Cham, 2015: pp. 141-184. doi:10.1007/978-3-319-16510-3.

[21] K. Mattsson, M.T. Ekvall, L.-A. Hansson, S. Linse, A. Malmendal, T. Cedervall, Altered Behavior, Physiology, and Metabolism in Fish Exposed to Polystyrene Nanoparticles, Environ. Sci. Technol. 49 (2015) 553-561. doi:10.1021/es5053655.

[22] M. Eriksen, L.C.M. Lebreton, H.S. Carson, M. Thiel, C.J. Moore, J.C. Borerro, F. Galgani, P.G. Ryan, J. Reisser, Plastic Pollution in the World's Oceans: More than 5 Trillion Plastic Pieces Weighing over 250,000 Tons Afloat at Sea, PLoS ONE. 9 (2014) e111913. doi:10.1371/journal.pone.0111913.

[23] L. Van Cauwenberghe, C.R. Janssen, Microplastics in bivalves cultured for human consumption, Environ. Pollut. 193 (2014) 65-70. doi:10.1016/j.envpol.2014.06.010.

[24] R.C. Thompson, Microplastics in the Marine Environment: Sources, Consequences and Solutions, in: M. Bergmann, L. Gutow, M. Klages (Eds.), Mar. Anthropog. Litter, Springer International Publishing, Cham, 2015: pp. 185-200. doi:10.1007/978-3-319-16510-3.

[25] A.A. Koelmans, E. Besseling, W.J. Shim, Nanoplastics in the Aquatic Environment. Critical Review, in: M. Bergmann, L. Gutow, M. Klages (Eds.), Mar. Anthropog. Litter, Springer International Publishing, Cham, 2015: pp. 325-342. doi:10.1007/978-3-31916510-3.

[26] T.S. Galloway, Micro- and Nano-plastics and Human Health, in: M. Bergmann, L. Gutow, M. Klages (Eds.), Mar. Anthropog. Litter, Springer International Publishing, Cham, 2015. doi:10.1007/978-3-319-16510-3.

[27] J. Wang, M.C. Baker, A. Bera, K. Kim, R. Lohmann, D. Ofiara, Y. Zhao, Marine Debris, in: L. Inniss, A. Simcock, United Nations (Eds.), First Glob. Integr. Mar. Assess. World Ocean Assess. I, Cambridge University Press, Cambridge, United Kingdom ; New York, 2017: pp. 389-408.

[28] A. Cózar, E. Martí, C.M. Duarte, J. García-de-Lomas, E. van Sebille, T.J. Ballatore, V.M. Eguíluz, J.I. González-Gordillo, M.L. Pedrotti, F. Echevarría, R. Troublè, X. Irigoien, The Arctic Ocean as a dead end for floating plastics in the North Atlantic branch of the Thermohaline Circulation, Sci. Adv. 3 (2017) e1600582. doi:10.1126/sciadv.1600582.

[29] D. Carrington, Plastic polluted Arctic islands are dumping ground for Gulf Stream, The Guardian. (2017). https://www.theguardian.com/environment/2017/jun/16/plastic-pollutedarctic-islands-are-dumping-ground-for-gulf-stream.

[30] A. Cozar, F. Echevarria, J.I. Gonzalez-Gordillo, X. Irigoien, B. Ubeda, S. Hernandez-Leon, A.T. Palma, S. Navarro, J. Garcia-de-Lomas, A. Ruiz, M.L. Fernandez-de-Puelles, C.M. Duarte, Plastic debris in the open ocean, Proc. Natl. Acad. Sci. 111 (2014) 10239-10244. doi:10.1073/pnas.1314705111.

[31] G. Gerdts, M.G.J. Löder, Methodology Used for the Detection and Identification of Microplastics-A Critical Appraisal, in: M. Bergmann, L. Gutow, M. Klages (Eds.), Mar. Anthropog. Litter, Springer International Publishing, Cham, 2015: pp. 201-228. doi:10.1007/978-3-319-16510-3. 
[32] M. Fisner, A.P. Majer, D. Balthazar-Silva, D. Gorman, A. Turra, Quantifying microplastic pollution on sandy beaches: the conundrum of large sample variability and spatial heterogeneity, Environ. Sci. Pollut. Res. 24 (2017) 13732-13740. doi:10.1007/s11356-0178883-y.

[33] M.E. Iñiguez, J.A. Conesa, A. Fullana, Marine debris occurrence and treatment: A review, Renew. Sustain. Energy Rev. 64 (2016) 394-402. doi:10.1016/j.rser.2016.06.031.

[34] P.G. Ryan, Does size and buoyancy affect the long-distance transport of floating debris?, Environ. Res. Lett. 10 (2015) 084019. doi:10.1088/1748-9326/10/8/084019.

[35] P.G. Ryan, A Brief History of Marine Litter Research, in: M. Bergmann, L. Gutow, M. Klages (Eds.), Mar. Anthropog. Litter, Springer International Publishing, Cham, 2015: pp. 1-28. doi:10.1007/978-3-319-16510-3.

[36] L.C. Woodall, A. Sanchez-Vidal, M. Canals, G.L.J. Paterson, R. Coppock, V. Sleight, A. Calafat, A.D. Rogers, B.E. Narayanaswamy, R.C. Thompson, The deep sea is a major sink for microplastic debris, R. Soc. Open Sci. 1 (2014) 140317-140317. doi:10.1098/rsos. 140317.

[37] D. Hohn, Sea of Trash, N. Y. Times Mag. (2008). http://www.nytimes.com/2008/06/22/magazine/22Plastics-t.html.

[38] C. Wilcox, E. Van Sebille, B.D. Hardesty, Threat of plastic pollution to seabirds is global, pervasive, and increasing, Proc. Natl. Acad. Sci. 112 (2015) 11899-11904. doi:10.1073/pnas.1502108112.

[39] S. Kuhn, E.L. Bravo Rebolledo, J.A. van Franeker, Deleterious Effects of Litter on Marine Life, in: M. Bergmann, L. Gutow, M. Klages (Eds.), Mar. Anthropog. Litter, Springer International Publishing, Cham, 2015: pp. 75-116. doi:10.1007/978-3-319-16510-3.

[40] C.G. Avio, S. Gorbi, F. Regoli, Plastics and microplastics in the oceans: From emerging pollutants to emerged threat, Mar. Environ. Res. 128 (2017) 2-11. doi:10.1016/j.marenvres.2016.05.012.

[41] C. Wilcox, N.J. Mallos, G.H. Leonard, A. Rodriguez, B.D. Hardesty, Using expert elicitation to estimate the impacts of plastic pollution on marine wildlife, Mar. Policy. 65 (2016) 107-114. doi:10.1016/j.marpol.2015.10.014.

[42] M.A. Browne, A.J. Underwood, M.G. Chapman, R. Williams, R.C. Thompson, J.A. van Franeker, Linking effects of anthropogenic debris to ecological impacts, Proc. R. Soc. B Biol. Sci. 282 (2015) 20142929-20142929. doi:10.1098/rspb.2014.2929.

[43] A. Lusher, Microplastics in the Marine Environment: Distribution, Interactions and Effects, in: M. Bergmann, L. Gutow, M. Klages (Eds.), Mar. Anthropog. Litter, Springer International Publishing, Cham, 2015: pp. 245-308. doi:10.1007/978-3-319-16510-3.

[44] M. Bergmann, L. Gutow, M. Klages, eds., Marine Anthropogenic Litter, Springer International Publishing, Cham, 2015. doi:10.1007/978-3-319-16510-3.

[45] K. Tanaka, H. Takada, R. Yamashita, K. Mizukawa, M. Fukuwaka, Y. Watanuki, Accumulation of plastic-derived chemicals in tissues of seabirds ingesting marine plastics, Mar. Pollut. Bull. 69 (2013) 219-222. doi:10.1016/j.marpolbul.2012.12.010.

[46] M. Kedzierski, M. D’Almeida, A. Magueresse, A. Le Grand, H. Duval, G. César, O. Sire, S. Bruzaud, V. Le Tilly, Threat of plastic ageing in marine environment. Adsorption/desorption of micropollutants, Mar. Pollut. Bull. 127 (2018) 684-694. doi:10.1016/j.marpolbul.2017.12.059.

[47] C.M. Rochman, E. Hoh, T. Kurobe, S.J. Teh, Ingested plastic transfers hazardous chemicals to fish and induces hepatic stress, Sci. Rep. 3 (2013). doi:10.1038/srep03263. 
[48] P. Wardrop, J. Shimeta, D. Nugegoda, P.D. Morrison, A. Miranda, M. Tang, B.O. Clarke, Chemical Pollutants Sorbed to Ingested Microbeads from Personal Care Products Accumulate in Fish, Environ. Sci. Technol. 50 (2016) 4037-4044. doi:10.1021/acs.est.5b06280.

[49] P. Farrell, K. Nelson, Trophic level transfer of microplastic: Mytilus edulis (L.) to Carcinus maenas (L.), Environ. Pollut. 177 (2013) 1-3. doi:10.1016/j.envpol.2013.01.046.

[50] O.M. Lönnstedt, P. Eklöv, Environmentally relevant concentrations of microplastic particles influence larval fish ecology, Science. 352 (2016) 1213-1216. doi:10.1126/science.aad8828.

[51] J.B. Lamb, B.L. Willis, E.A. Fiorenza, C.S. Couch, R. Howard, D.N. Rader, J.D. True, L.A. Kelly, A. Ahmad, J. Jompa, C.D. Harvell, Plastic waste associated with disease on coral reefs, Science. 359 (2018) 460-462. doi:10.1126/science.aar3320.

[52] J.T. Carlton, J.W. Chapman, J.B. Geller, J.A. Miller, D.A. Carlton, M.I. McCuller, N.C. Treneman, B.P. Steves, G.M. Ruiz, Tsunami-driven rafting: Transoceanic species dispersal and implications for marine biogeography, Science. 357 (2017) 1402-1406. doi:10.1126/science.aao1498.

[53] S. Newman, E. Watkins, A. Farmer, P. ten Brink, J.-P. Schweitzer, The Economics of Marine Litter, in: M. Bergmann, L. Gutow, M. Klages (Eds.), Mar. Anthropog. Litter, Springer International Publishing, Cham, 2015: pp. 367-394. doi:10.1007/978-3-31916510-3.

[54] A.L. Lusher, M. McHugh, R.C. Thompson, Occurrence of microplastics in the gastrointestinal tract of pelagic and demersal fish from the English Channel, Mar. Pollut. Bull. 67 (2013) 94-99. doi:10.1016/j.marpolbul.2012.11.028.

[55] C.M. Rochman, A. Tahir, S.L. Williams, D.V. Baxa, R. Lam, J.T. Miller, F.-C. Teh, S. Werorilangi, S.J. Teh, Anthropogenic debris in seafood: Plastic debris and fibers from textiles in fish and bivalves sold for human consumption, Sci. Rep. 5 (2015). doi:10.1038/srep14340.

[56] The New Plastics Economy — Rethinking the future of plastics, World Economic Forum, 2016.

[57] M.J. Bean, Legal strategies for reducing persistent plastics in the marine environment, Mar. Pollut. Bull. 18 (1987) 357-360. doi:10.1016/S0025-326X(87)80026-7.

[58] T. O'Brine, R.C. Thompson, Degradation of plastic carrier bags in the marine environment, Mar. Pollut. Bull. 60 (2010) 2279-2283. doi:10.1016/j.marpolbul.2010.08.005.

[59] O.S. Ogunola, O.A. Onada, A.E. Falaye, Mitigation measures to avert the impacts of plastics and microplastics in the marine environment (a review), Environ. Sci. Pollut. Res. 25 (2018) 9293-9310. doi:10.1007/s11356-018-1499-z.

[60] M.A. Browne, Sources and Pathways of Microplastics to Habitats, in: M. Bergmann, L. Gutow, M. Klages (Eds.), Mar. Anthropog. Litter, Springer International Publishing, Cham, 2015: pp. 229-244. doi:10.1007/978-3-319-16510-3.

[61] D. Xanthos, T.R. Walker, International policies to reduce plastic marine pollution from single-use plastics (plastic bags and microbeads): A review, Mar. Pollut. Bull. 118 (2017) 17-26. doi:10.1016/j.marpolbul.2017.02.048.

[62] F. Convery, S. McDonnell, S. Ferreira, The most popular tax in Europe? Lessons from the Irish plastic bags levy, Environ. Resour. Econ. 38 (2007) 1-11. doi:10.1007/s10640-0069059-2. 
[63] Q. Schuyler, B.D. Hardesty, T. Lawson, K. Opie, C. Wilcox, Economic incentives reduce plastic inputs to the ocean, Mar. Policy. (2018). doi:10.1016/j.marpol.2018.02.009.

[64] C.M. Rochman, M.A. Browne, A.J. Underwood, J.A. van Franeker, R.C. Thompson, L.A. Amaral-Zettler, The ecological impacts of marine debris: unraveling the demonstrated evidence from what is perceived, Ecology. 97 (2016) 302-312. doi:10.1890/14-2070.1.

[65] D. Carrington, Scientists accidentally create mutant enzyme that eats plastic bottles, The Guardian. (2018).

[66] H.P. Austin, M.D. Allen, B.S. Donohoe, N.A. Rorrer, F.L. Kearns, R.L. Silveira, B.C. Pollard, G. Dominick, R. Duman, K. El Omari, V. Mykhaylyk, A. Wagner, W.E. Michener, A. Amore, M.S. Skaf, M.F. Crowley, A.W. Thorne, C.W. Johnson, H.L. Woodcock, J.E. McGeehan, G.T. Beckham, Characterization and engineering of a plastic-degrading aromatic polyesterase, Proc. Natl. Acad. Sci. (2018) 201718804. doi:10.1073/pnas. 1718804115.

[67] N. Wierckx, T. Narancic, C. Eberlein, R. Wei, O. Drzyzga, A. Magnin, H. Ballerstedt, S.T. Kenny, E. Pollet, L. Avérous, K.E. O’Connor, W. Zimmermann, H.J. Heipieper, A. Prieto, J. Jiménez, L.M. Blank, Plastic Biodegradation: Challenges and Opportunities, in: R. Steffan (Ed.), Consequences Microb. Interact. Hydrocarb. Oils Lipids Biodegrad. Bioremediation, Springer International Publishing, Cham, 2018: pp. 1-29. doi:10.1007/9783-319-44535-9_23-1.

[68] R. Wei, W. Zimmermann, Microbial enzymes for the recycling of recalcitrant petroleumbased plastics: how far are we?, Microb. Biotechnol. 10 (2017) 1308-1322. doi:10.1111/1751-7915.12710.

[69] R. Wei, W. Zimmermann, Biocatalysis as a green route for recycling the recalcitrant plastic polyethylene terephthalate, Microb. Biotechnol. 10 (2017) 1302-1307. doi:10.1111/17517915.12714.

[70] D. Parker, The Great Pacific Garbage Patch, (2018). https://oceanservice.noaa.gov/podcast/mar18/nop14-ocean-garbage-patches.html. 